\title{
Algal Diversity of the Pamir High Mountain Mineral Springs in Environmental Variables Gradient
}

\author{
Barinova $\mathrm{SS}^{1 *}$ and Niyatbekov $\mathrm{TP}^{2}$ \\ ${ }^{1}$ Institute of Evolution, University of Haifa, Israel \\ ${ }^{2}$ Plant Physiology and Genetics, Institute of Botany, Tajikistan
}

Submission: November 16, 2017; Published: November 30, 2017

*Corresponding author: Barinova SS, Institute of Evolution, University of Haifa, Mount Carmel, 199 Abba Khoushi Ave, Haifa 3498838, Israel, Email: sophia@evo.haifa.ac.il

\begin{abstract}
Paper represents the results of our study in Pamir mineral and hot springs. Altogether 134 diatom species (166 with infraspecific taxa) were revealed from 150 periphytonic samples. The correlation of species richness with habitat altitude in the Pamir high mountains was identified with help of the Distance Weighted Least Square method in Statistica 12.0 program. It has been conclude that both global related parameters altitude and temperature can define the algal communities' development in high mountain habitats of Pamir. The special factor, water $\mathrm{pH}$ was revealed as regulating parameter for diatom species richness in studied hot and mineral water springs. The infraspecific variability index that we calculated for Pamir mineral springs communities of diatom algae was 1.24, and was highest in comparison of regional high mountain algal floras. Index is increased with habitat altitude and show high adaptation potential of Pamir diatoms.
\end{abstract}

Keywords: Algae; Pamir; Mineral water sources; Altitude

\section{Introduction}

The algal biodiversity and environmental conditions relationships are determined by adaptation level of the species and the community. When operating with alpha-diversity of freshwater algae we use a multilevel approach with the hierarchy of levels such as infraspecies variation level, species composition, community composition, and flora of a water body [1]. Up to now it is still a problem to define the role of particular environmental variables as well as to predict the community's response to environmental change [2]. One of the major climatically related parameter is the altitude of algal community habitat. We give attention earlier to the freshwater community response on the high mountain areas climatic gradients [3-10]. But up to now we studied habitats on the altitude up to $2,500 \mathrm{~m}$. In this is very important to study climatic factors influence on the algal communities of long-term stabile environments such as high mountain mineral water sources. One of the highest mountain areas of Eurasia is Pamir that closely related to Hindu Cush and Himalayas. A study of the species composition of algae, including the diatoms (Bacillariophyta), inhabiting thermal and mineral springs is of great scientific interest that was our aim of work.

\section{Description of study site and referenced data}

Pamir is very rich in thermal and mineral waters, which in a way are unique habitats characterized by a constantly and high temperature from $10{ }^{\circ} \mathrm{C}$ to $86{ }^{\circ} \mathrm{C}$ and various chemical compositions saturated with carbon dioxide and nitrogen gases such as hydrogen sulfide-siliceous, hydrocarbonatesulphate-calcium-magnesium, chloride-sulfate-calcium-sodium, hydrocarbonate-sulfate-sodium and weak radon-chloridesulfate [11-12]. In these waters, for many centuries, a special community of algae with a specific species composition and degree of species resistance to peculiarly extreme environmental conditions was formed and developed. The referenced literature data on Pamir regional flora is known from sporadically collected material in period 1930-1983 [13-17]. The regular work was started by G.R. Jumaeva in 2000 and continued up to 2006 [18]. Altogether 114 diatom species (157 with infraspecific taxa) were revealed for thermal and mineral springs of Pamir before our study.

\section{Material and Methods}

The material for this analysis is represented by our own data from 150 samples collected during few field trips in summer period of 2000-2015 from various sources Jelandy, Avdzh, Garm-Chashma, Sassykbulak, Sist and Barshor located at an altitude from $2,360 \mathrm{~m}$ to $3,800 \mathrm{~m}$, above the sea level (Figure 1). Algal periphytonic samples were collected and processed from various places, springs, and griffins with a water temperature of $10{ }^{\circ} \mathrm{C}$ to $86^{\circ} \mathrm{C}$ (Table 1 ). The statistical methods were chosen in accordance to analytical purposes using the program Statistica 12.0. 


\section{International Journal of Environmental Sciences \& Natural Resources}

Table 1: Diatom species richness in the mineral water springs of Pamir and the major variables of habitats with geographical coordinates.

\begin{tabular}{|c|c|c|c|c|c|c|}
\hline Pamir Region & West & West & West & West & East & East \\
\hline Name of spring & Barshor & Sist & Garm-Chashma & Avadzh & Jelandy & Sassykbulak \\
\hline No of water spring & 1 & 2 & 3 & 4 & 5 & 6 \\
\hline Species & 13 & 9 & 15 & 41 & 76 & 13 \\
\hline Infraspecies & 18 & 9 & 18 & 48 & 93 & 14 \\
\hline Ssp/Sp Index & 1.38 & 1 & 1.2 & 1.17 & 1.22 & 1.08 \\
\hline Altitude, $\mathrm{m}$ a.s.l. & 2,400 & 2,360 & 2,800 & 2,410 & 3,600 & 3,800 \\
\hline Temperature, ${ }^{\circ} \mathrm{C}$ & $10-15$ & $10-12$ & $40-62$ & 35 & $21-86$ & 22 \\
\hline $\mathrm{pH}$ & 6.4 & 5.8 & 7.1 & 7.1 & 7.8 & 7.4 \\
\hline North & $37^{\circ} 00^{\prime} 98.02^{\prime \prime}$ & $37^{\circ} 10^{\prime} 18.26^{\prime \prime}$ & $37^{\circ} 12^{\prime} 11.06^{\prime \prime}$ & $37^{\circ} 12^{\prime} 19.06^{\prime \prime}$ & $37^{\circ} 34^{\prime} 30.84^{\prime \prime}$ & $37^{\circ} 40^{\prime} 84.90^{\prime \prime}$ \\
\hline East & $71^{\circ} 30^{\prime} 21.89^{\prime \prime}$ & $71^{\circ} 30^{\prime} 19.87^{\prime \prime}$ & $71^{\circ} 32^{\prime} 11.18^{\prime \prime}$ & $71^{\circ} 31^{\prime} 90.51^{\prime \prime}$ & $72^{\circ} 34^{\prime} 41.93^{\prime \prime}$ & $73^{\circ} 00^{\prime} 22.54^{\prime \prime}$ \\
\hline
\end{tabular}

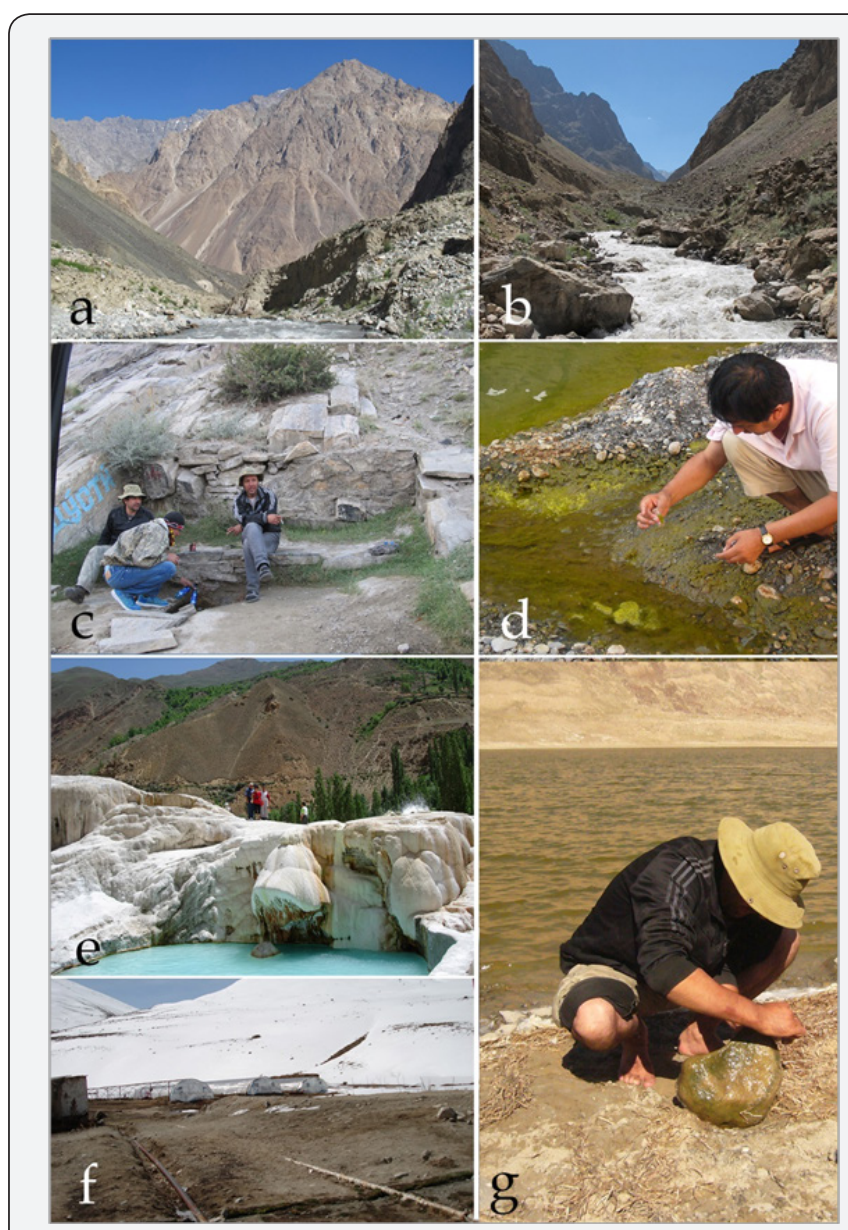

Figure 1: The mineral water sources of Pamir: a, ravine Gunt; b, ravine Jelandy; c, Barshor; d, Avadzh; e, Garm-Chashma; f, Jelandy; $g$, algal samples collecting in the lake of Yashilkul.

\section{Results and Discussion}

As can be seen in (Table 1), the maximal water temperature of springs is fluctuated in large range. Active water proton concentration have also range from acidic $\mathrm{pH}$ in the Sist spring to low alkaline in the Jelandy hot springs. Altogether 134 diatom species (166 with infraspecific taxa) were revealed from 150 periphytonic samples. Low-alkaline hot springs of Jelandy and
Avdzh have richest diatom community with 76 and 41 species respectively. In contrary, acidic water communities of Sist and Barshor were represented by 9 and 13 species respectively. This data let us to assume that water $\mathrm{pH}$ can regulate species richness of studied water springs in Pamir. Especial interest is represented the species richness distribution over the altitude gradient (Figure 2) show that specific and infraspecific data are fluctuated synchronously over the altitude of spring habitats. Species richness is increased with altitude excluding the Sassykbulak spring community only which is placed on the altitude of $3,800 \mathrm{~m}$ a.s.l. May be this spring has some special factors that inhibit the development of diatoms at this altitude such as water debit or temperature.

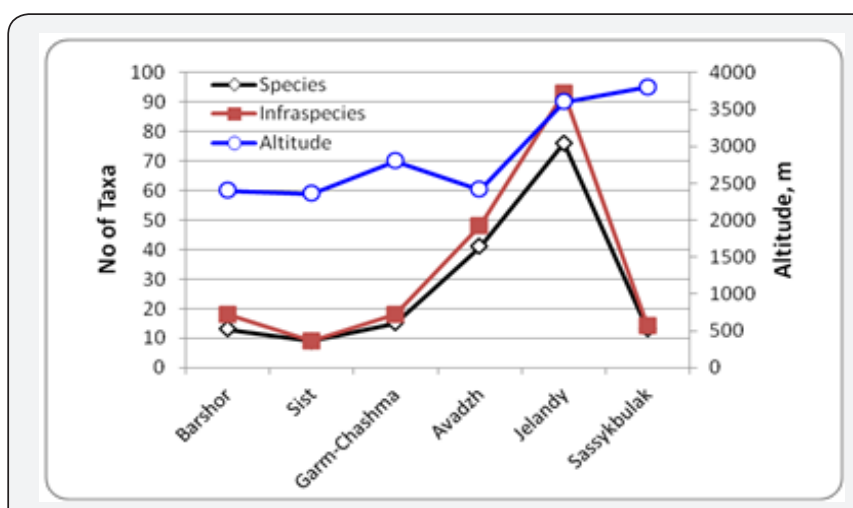

Figure 2: Diatom species richness in the mineral water springs of Pamir and altitude of its habitats.

We calculated earlier the index of infraspecific variation (Ssp/Sp Index) that was correlated not only with algal community habitat altitude but also with the geographical position of water body in respect of it latitude in the Northern Hemisphere [3,5-10]. The algal floras of close related high mountain areas all consists the diatom algae as about half of the species list [19]. Therefore, our calculation of Ssp/Sp Index results can be comparable with other regional floras and reflect the adaptation style of the algal flora as a whole. Ssp/Sp index is increase with altitude of habitats of mentioned regional floras such as in Hindu Cush, Caucasus, South-Tajik depression or Iran that was calculated by us on the base of [20] as 1.19 . Figure 3 shows infraspecific variation Index in the mineral water springs 
of Pamir which is about 1.24 and fluctuated in opposite direction with habitats altitude as can be recognize in the trend lines. This is highest index value for the studied region in the area with highest altitude.

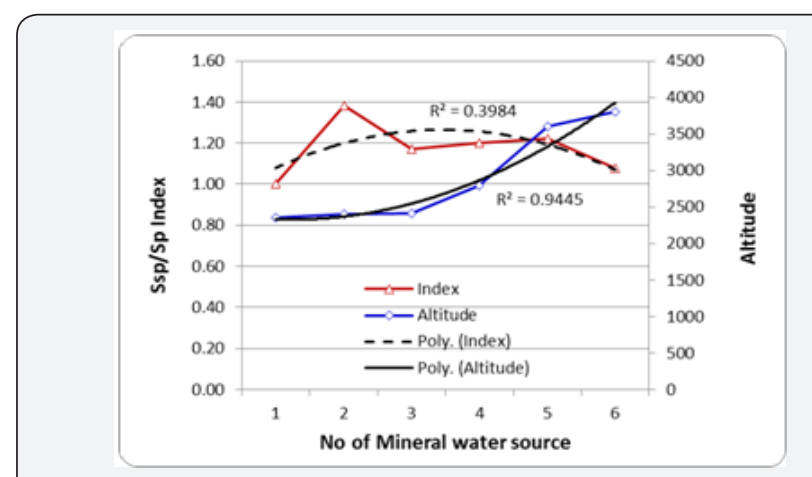

Figure 3: Infracpecific variation Index in the mineral water springs of Pamir and habitats altitude. No of springs as in Table 1.

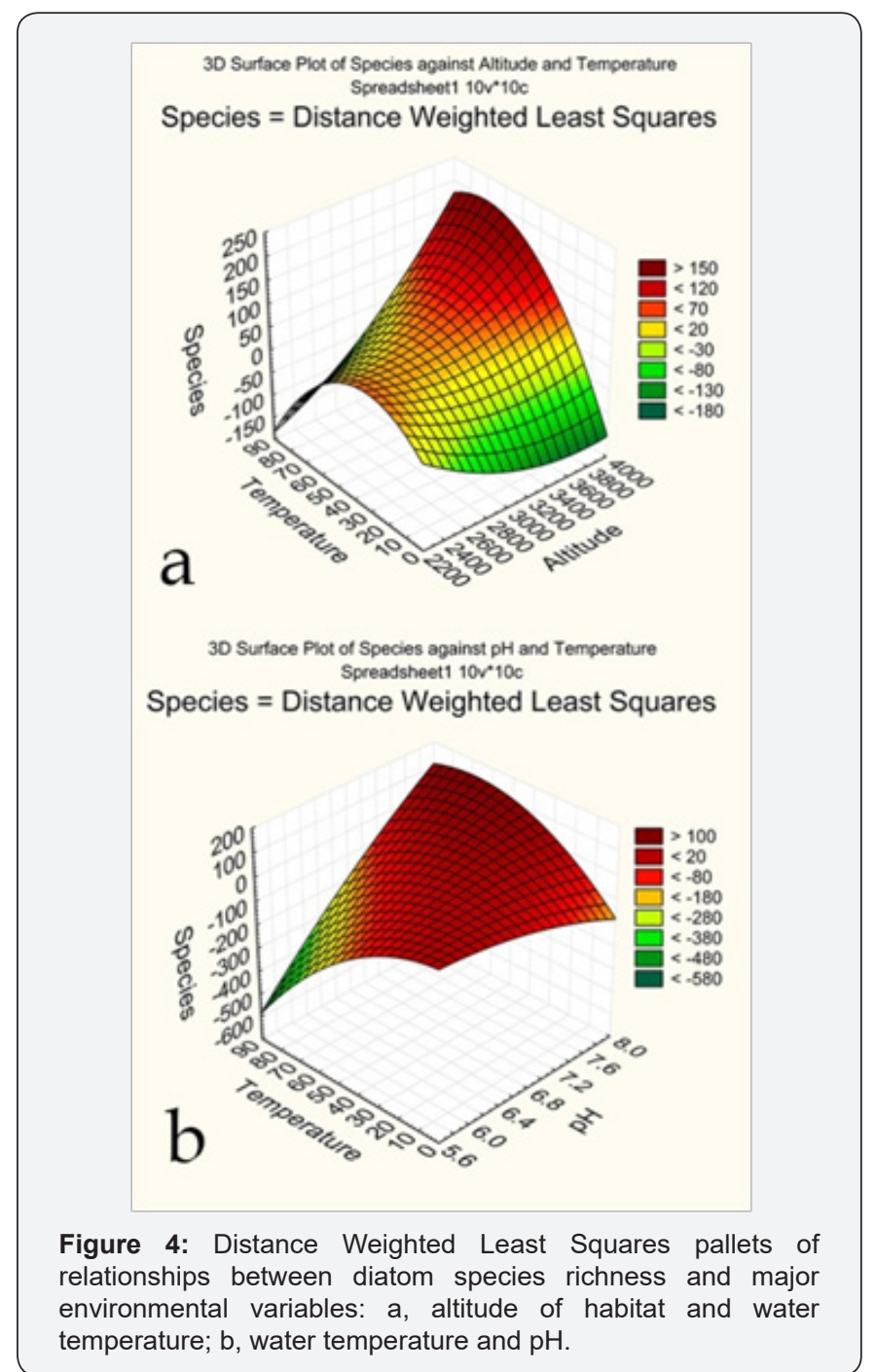

The basic macro-climatic variables that support of photosynthetic activity are the sunlight and temperature. However, the same factors are the global and defined the life and evolution [21]. It is difficult to compare the global temperature fluctuation and algal communities development because the data are or not enough, or have incomparable scale. But in our material we compare the distribution of diatom species richness over major environmental variables that partly are climaticallyrelated and partly are represent especial characteristics of mineral springs (Figure 4). Statistically generated surfaces of distribution on the base of Table 1 data show that water temperature in mineral springs of Pamir is stimulating factor for diatom species richness (Figure 4a) which increased with altitude. In the same time, low-alkaline water $\mathrm{pH}$ also stimulates algal diversity but in lowermost temperature waters only (Figure 4b).

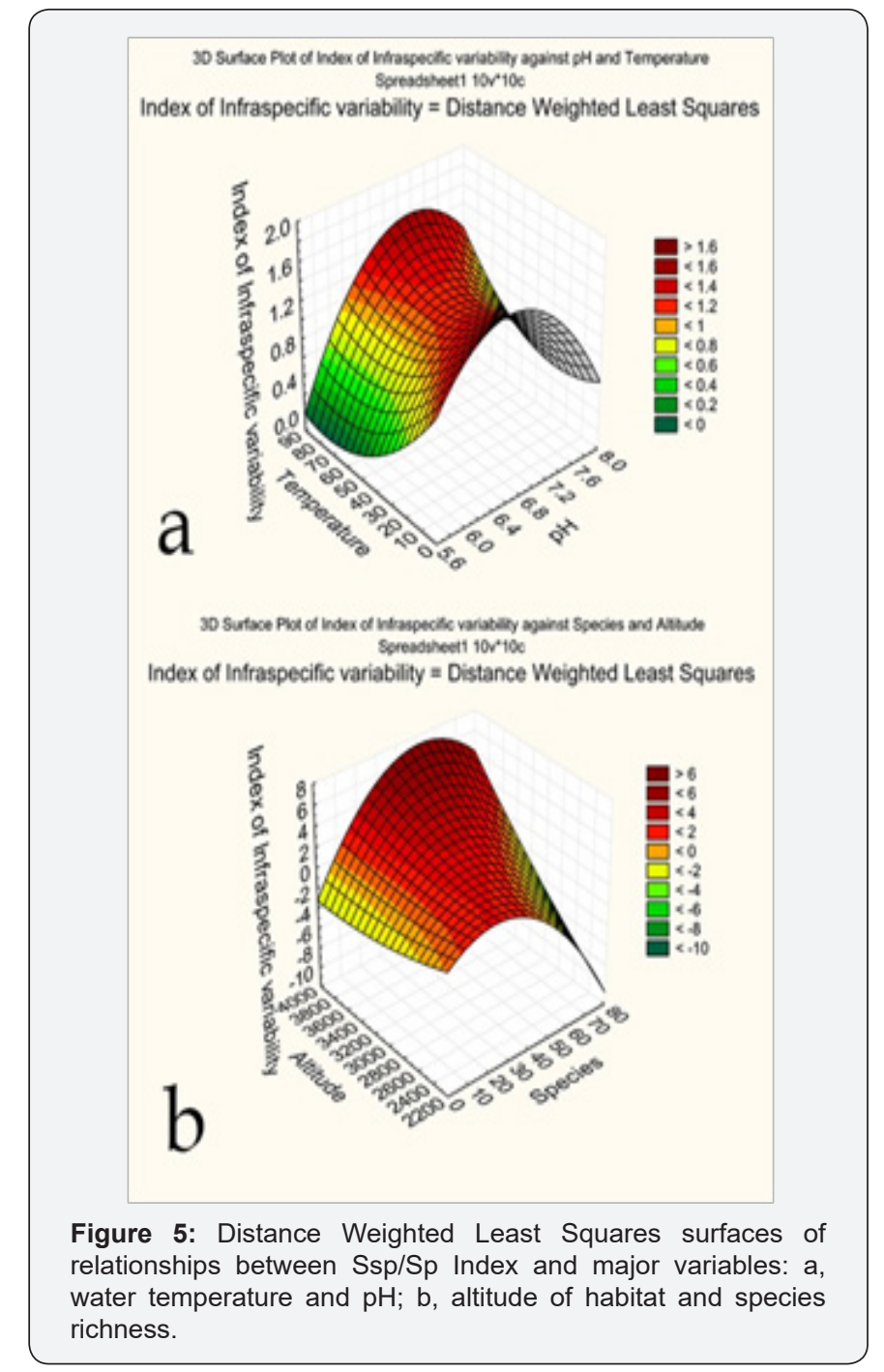

Calculation of the Distance Weighted Squares surfaces for $\mathrm{Ssp} / \mathrm{Sp}$ Index is revealing a complex dependence of it on water temperature and $\mathrm{pH}$. Figure $5 \mathrm{a}$ demonstrates that infraspecific variability is highest in the circumneutral waters, whereas the water temperature was not so influenced by it. Figure $5 b$ represented the tendency of infraspecific variability increasing for the high altitude communities where species richness was not so large. This calculation let us to assume that altitude of habitat play the major role in infraspecific variability of diatom 
algae in Pamir mineral and hot springs as a mechanism for species protection from the environmental stress for future surviving and development.

\section{Conclusion}

The gradient of solar radiation and temperature is define not only species richness of algal communities as a whole but also species content [22] that was revealed in the high latitude habitats $[2,21,23]$. Because these pair of climatically related parameters is fluctuated synchronously and we revealed correlation of species richness with habitat altitude in the Pamir high mountains that mean that both global related parameters can define the algal communities' development in the studied high mountain habitats in Pamir. Our study represents altogether 134 diatom species (166 with infraspecific taxa). The special factor, water $\mathrm{pH}$ was found as regulating parameters for diatom species richness of studied hot and mineral water springs in Pamir. The infraspecific variability index calculated for Pamir mineral springs communities of diatom algae was 1.24 . This is highest value in comparison of close high mountain regional floras. Index is increased with habitat altitude and show high adaptation potential of Pamir diatoms.

\section{Acknowledgement}

This work has been partly supported by the Israeli Ministry of Absorption.

\section{References}

1. Barinova S (2013) Multilevel approach in biodiversity analysis of freshwater algae. Expert Opinion on Environmental Biology 2(2): 1-2.

2. Barinova S, Gabyshev V, Boboev M, Kukhaleishvili L, Bilous 0 (2015) Algal Indication of Climatic Gradients. American Journal of Environmental Protection 4 (3-1): 72-77.

3. Barinova S (2011) The effect of altitude on distribution of freshwater algae in continental Israel. Current Topics in Plant Biology 12: 89-95.

4. Barinova S, Boboev M, Hisoriev H (2015) Freshwater algal diversity of the South-Tajik Depression in a high mountainous extreme environment. Turkish Journal of Botany 39: 535-546.

5. Barinova SS, Kukhaleishvili L, Nevo E, Janelidze Z (2011) Diversity and ecology of algae in the Algeti National Park as a part of the Georgian system of protected areas. Turkish Journal of Botany 35: 729-774.

6. Barinova S, Kukhaleishvili L (2014) Diversity and ecology of algae and cyanobacteria in the Aragvi River, Georgia. The Journal of Biodiversity 113: 305-338.

7. Barinova S, Kukhaleishvili L (2017) Diversity and ecology of algae and cyanobacteria in the Enguri River, Georgia. Elixir Bio Science, 104: 45934-45947.
8. Barinova S, Naiz Ali, Barkatullah, Sarim FM (2013) Ecological Adaptation to Altitude of Algal Communities in the Swat Valley (Hindu Cush Mountains, Pakistan). Expert Opinion on Environmental Biology 2(2): 1-15.

9. Khuram I, Barinova S, Ahmad N, Ullah A, SirajUd Din, et al. (2017) Ecological assessment of water quality in the Kabul River, Pakistan, using statistical methods. Oceanological and Hydrobiological Studies 46(2): 140-153.

10. Bokhodjaev IYa, Davlatmamadov ShM (1994) Medical mineral springs of Pamir. Dushanbe.

11. Churshina NM (1982) Mineral, thermal and cold water. In: Tajikistan (nature and natural resources). Dushanbe pp. 125-131.

12. Petersen JB (1930) Algae from O. Olufsen's second Danish Pamir Expedition 1898-1899. Dansk Bot Ark 6(6): 1-60.

13. Balashova NB, Nikitina VN (1978) To the algal flora of some thermal springs of Pamir. Proceedings of VI conference of lower plants of Middle Asia and Kazakhstan. Donish, Dushanbe p. 1-22.

14. Muzafarov AM (1965) Algal flora of the Central Asian water bodies. Tashkent, Uzbekistan Academy of Science Publisher.

15. Ergashev AE (1969) Materials to the algal floras of natural and artificial, thermal and hot springs of Middle Asia. Lower Plants of Middle Asia. Tashkent, Fan 10(3): 3-37.

16. Baturina LR (1983) Algae of thermal springs of Tajikistan. PhD Thesis, Dushanbe pp. 1- 284.

17. Jumaeva GR (2008) Algal flora of major thermal and mineral springs of Pamir. PhD Thesis, Dushanbe pp. 1- 151.

18. Boboev MT, Barinova S (2016) The comparative analysis of the SouthTajik depression algal flora with selected floras of Eurasia. Proceedings of II International Conference "Actual problems of the development of world science", 26 March, Kiev, Ukraine, 2: 14-19.

19.Zarei Darki B (2009) Taxonomic structure of the algal flora of Iran. Bangladesh J Plant Taxon 16(2): 185-194.

20. Barinova S (2017) Influence of Macro-Environmental Climatic Factors on Distribution and Productivity of Freshwater Algae. Int J Environ Sci Nat Res, 4(1).

21. Barinova S, Gabyshev V, Gabysheva O (2014) Climate impact of freshwater biodiversity: general patterns in extreme environments of North-Eastern Siberia (Russia). British Journal of Environment and Climate Change 4(4): 423-443.

22. Denisov DB, Barinova S (2015) Algal diversity and ecological variables in the Arctic lakes of the Kola Peninsula, Russian North. Issues of Modern Algology 2(9): 1-47.

23. Denisov DB, Barinova S (2016) Phytoperiphyton and environmental variables in the rivers of the Kola Peninsula, Russian Arctic North. Issues of Modern Algology 1(11): 1-16. 
Your next submission with Juniper Publishers will reach you the below assets

- Quality Editorial service

- Swift Peer Review

- Reprints availability

- E-prints Service

- Manuscript Podcast for convenient understanding

- Global attainment for your research

- Manuscript accessibility in different formats

( Pdf, E-pub, Full Text, Audio)

- Unceasing customer service

Track the below URL for one-step submission https://juniperpublishers.com/online-submission.php 